\title{
Penerapan Restorative Justice sebagai Model Perlindungan terhadap Anak (Studi Penanganan Perkara Anak Berhadapan dengan Hukum pada Wilayah Hukum Pengadilan Negeri Dumai Kelas IA)
}

\section{Application of Restorative Justice as a Model of Child Protection (Study of the Case Management of Children Facing the Law in the Dumai District Court Legal Class IA)}

\author{
Muhammad Sacral Ritonga, Mahmud Mulyadi \& Mustamam \\ Program Studi Magister Hukum, Fakultas Hukum Universitas Islam Sumatera Utara, Indonesia
}

Diterima: Desember 2019; Disetujui: Desember 2019; Dipublish: Desember 2019

*Coresponding Email: emveliamegasaragih@gmail.com

\begin{abstract}
Abstrak
Permasalahan dalam penelitian ini, mengenai konsep restorative justice dalam Undang-undang Nomor 11 Tahun 2012 Tentang Sistem Peradilan Pidana Anak, dan mengenai konsep restorative justice sebagai upaya memberi Perlindungan terhadap Anak yang berhadapan dengan hukum, serta faktor yang menjadi hambatan dan solusi dalam pelaksanaan restorative justice di Wilayah Hukum Pengadilan Negeri Dumai Kelas IA. Penelitian ini merupakan penelitian yuridis empiris dengan mengadakan penelitian di lembaga/instansi penegak hukum di wilayah hukum Pengadian Negeri Dumai Kelas IA, mengenai pelaksanaan restorative justice di Wilayah Hukum Pengadilan Negeri Dumai Kelas IA. Penelitian ini bersifat deskriptif analisis, dengan menggunakan sumber primer dan sekunder. Analisis data yang digunakan dalam penelitian ini yaitu analisis data kualitatif. Berdasarkan hasil penelitian diperoleh, restorative justice dalam Undang-Undang SPPA dilaksanakan melalui Diversi pada setiap tingkat peradilan pidana anak. Diversi merupakan pengalihan penyelesaian perkara anak yang berhadapan dengan hukum dari proses formal (proses peradilan) ke proses informal dengan cara musyawarah dan mufakat yang mengedepankan keadilan restoratif. Restorative justice akan memberi Perlindungan terhadap ABH, karena melalui penerapan Diversi anak akan dijauhkan dari proses peradilan formal yang dimungkinkan terabaikannya hak-hak anak dan menimbulkan trauma bagi anak. Hambatan dalam pelaksanaan restorative justice di wilayah hukum Pengadilan Negeri Dumai kelas IA adalah masih kurangnya SDM aparatur penegak hukum. Sarana dan prasana pendukung masih sangat minim.

Kata Kunci: Penerapan, Restorative Justice, Perlindungan Anak.
\end{abstract}

\begin{abstract}
The problems in this study, concerning the concept of restorative justice in Law Number 11 of 2012 concerning the Child Criminal Justice System, and regarding the concept of restorative justice as an effort to provide protection for children who are faced with the law, and factors that become obstacles and solutions in implementing restorative justice in the Legal Area of the Class IA District Court of Dumai. This research is empirical juridical research, by conducting research at law enforcement agencies / institutions in the Dumai State IA Class law, concerning the implementation of restorative justice in the Legal Area of the Class IA District Court of Dumai. This research is descriptive analysis, using primary and secondary sources. Data analysis used in this study is qualitative data analysis. Based on the results of the research, the concept of restorative justice in the SPPA Act was implemented through the application of Diversion at every level of the juvenile justice process. Diversion is the transfer of settlement of child cases dealing with the law from the formal process (judicial process) to the formal process, by means of deliberation and consensus which prioritizes restorative justice. The concept of restorative justice will provide protection for ABH, because through the implementation of child diversification it will be kept away from the formal justice process which allows the neglect of children's rights and traumatizes children. The obstacle in the implementation of restorative justice in the legal court area of the IA Dumai class is still a lack of human resources law enforcement officers. Supporting facilities and infrastructures are still very minimal. There is still a lack of socialization to the community. Keywords: Application, Restorative Justice, Child Protection.
\end{abstract}

How to Cite: Ritonga, M. S., Mulyadi, M. \& Mustamam (2019). Penerapan Restorative Justice Sebagai Model Perlindungan terhadap Anak (Studi Penanganan Perkara Anak Berhadapan dengan Hukum pada Wilayah Hukum Pengadilan Negeri Dumai Kelas IA). Journal of Education, Humaniora and Social Sciences (JEHSS). 2 (2): 318-334. 


\section{PENDAHULUAN}

Undang-Undang SPPA lebih memberikan perlindungan hukum terhadap ABH, karena merumuskan beberapa ketentuan hukum yang sebelumnya tidak diatur dalam Undang-Undang Pengadilan Anak. Penjelasan Undang-Undang SPPA, menegaskan:

Anak adalah bagian yang tidak terpisahkan dari keberlangsungan hidup manusia dan keberlangsungan sebuah bangsa dan negara. Anak memiliki peran strategis yang secara tegas dinyatakan bahwa negara menjamin hak setiap anak atas kelangsungan hidup, tumbuh, dan berkembang serta atas perlindungan dari kekerasan dan diskriminasi, oleh karena itu, kepentingan terbaik bagi anak patut dihayati sebagai kepentingan terbaik bagi kelangsungan hidup umat manusia. Konsekuensi dari ketentuan Pasal 28 B Undang-Undang Dasar Negara Republik Indonesia Tahun 1945 perlu ditindak lanjuti dengan membuat kebijakan pemerintah yang bertujuan melindungi Anak.

Undang-Undang SPPA, menentukan bahwa dalam setiap tingkatan proses peradilan pidana anak, yaitu mulai dari penyidikan, penuntutan, dan pemeriksaan di muka persidangan peradilan pidana anak wajib dilaksanakan Diversi. Diversi adalah pengalihan penyelesaian perkara anak dari proses peradilan pidana ke proses di luar peradilan pidana. Dengan demikian, Diversi juga bermakna suatu upaya untuk mengalihkan anak dari proses yustisial menuju prises non-yustisial. Ketentuan mengenai Diversi yang diatur dalam Undang-Undang Sistem Peradilan Pidana merupakan perubahan dalam sistem peradilan anak (Purba \& Zahara, 2017; Sidabutar \& Suhatrizal, 2018; Ginting \& Muazzul. 2018).

Pelaksanaan Diversi dalam peradilan anak bertujuan untuk mencapai perdamaian antara korban dan Anak, menyelesaikan perkara anak di luar proses peradilan, menghindarkan anak dari perampasan kemerdekaan, mendorong masyarakat untuk berpartisipasi dan menanamkan rasa tanggung jawab kepada anak. Penerapan Diversi dalam proses peradilan anak bersifat wajib (imperatif) pada tingkat penyidikan, penuntutan, dan pemeriksaan perkara Anak di pengadilan “wajib” diupayakan Diversi.

Proses hukum formal merupakan jalan terakhir dalam menangani anak yang berkonflik dengan hokum (Waluyadi, 2010). Dalam penanganan anak yang berhadapan dengan hukum, penerapan konsep restorative justice merupakan konsep yang diterapkan dalam penyelesaian perkara anak yang anak yang berhadapan dengan hukum, dengan 
melibatkan semua pihak, termasuk pelaku sendiri (Marlina, 2009). Oleh karena itu, aparat penegak hukum, khususnya Polri tidak sesegera mungkin untuk membawa kasus yang dilakukan oleh anak ke jalur penyidikan, tetapi penyelesaian masalah tersebut lebih dahulu mengedepankan prinsip kemitraan (patnership) dan pemecahan masalah (problem solving).

\section{METODE PENELITIAN}

Penelitian ini bersifat deskriptif analisis, dengan menggunakan sumber primer dan sekunder. Analisis data yang digunakan dalam penelitian ini yaitu analisis data kualitatif. Beberapa teori yang relevan dalam menganalisis permasalahan penelitian yang dikemukakan pada penelitian ini, diantaranya adalah: teori keadilan restorative justice, teori perlindungan hukum (law protection theory) dan Teori sistem hukum (legal system theory).

Teori keadilan restorative, Konsep asli praktek keadilan restorative berasal dari praktik pemeliharaan perdamaian yang digunakan suku bangsa Maori, penduduk asli Selandia Baru Menurut Helen Cowie keadilan restorative pada intinya terletak pada konsep komunitas yang peduli dan inklusif (Supeno, 2015). Bilamana timbul konflik, praktek restorative justice akan menangani pihak pelaku, korban, dan para stakeholders komunitas tersebut, yang secara kolektif memecahkan masalah.

Peradilan model restorative berangkat dari asumsi bahwa anggapan atau reaksi terhadap perilaku delinkuensi anak tidak efektif tanpa adanya kerja sama dan keterlibatan dari korban, pelaku dan masyarakat. Prinsip yang menjadi dasar adalah bahwa keadilan paling baik terlayani apabila setiap pihak menerima perhatian secara adil dan seimbang, aktif dilibatkan dalam proses peradilan (Supeno, 2015)

Menurut Helen Cowie dan Dawn Jennifer dalam Hadi Supeno, mengidentifikasikan aspek-aspek utama keadilan restoratif sebagai berikut (Supeno, 2015): 1) Perbaikan, bukanlah tentang memperoleh kemenangan atau menerima kekalahan, tudingan, atau pembalasan dendam, tetapi tentang keadilan; 2) Pemulihan hubungan, bukan bersifat hukuman para pelaku criminal memikul tanggung jawab atas kekeliruan dan memperbaikinya dengan sejumlah cara, tetapi melalui proses komunikasi yang terbuka dan langsung, antara korban dan pelaku kriminal, yang berpotensi mengubah cara berhubungan satu sama lain; 3) Reintegrasi, pada tingkatnya yang terluas, memberikan 
arena tempat anak dan orang tua dapat memperoleh proses yang adil. Maksudnya agar mereka belajar tentang konsekuensi kekerasan dan kriminalias serta memahami dampak perilaku mereka terhadap orang lain.

Model keadilan restorative lebih pada upaya pemulihan hubungan pelaku dan korban, misalnya, seseorang mencuri buku, maka proses keadilannya adalah begaimana cara dan langkah apa agar persoalan bisa selesai sehingga hubungan baik antara orang tersebut dan professor berlangsung seperti semula tanpa ada yang dirugikan. Sedangkan keadilan retributive, masyarakat tidak dilibatkan karena sudah diwakilkan pengacara, sementara dalam keadilan restoratif masyarakat dilibatkan melalui tokoh-tokoh masyarakat yang memiliki kewibawaan dalam lingkungan tersebut, misalnya tokoh agama, orang berpengaruh, dan sebagainya (Supeno, 2015).

Teori perlindungan hukum (law protection theory), Negara Indonesia adalah Negara hukum, ide gagasan ini tercantum secara tegas dalam Pasal 1 ayat (3) Undang-Undang Dasar Negara Republik Indonesia Tahun 1945 amandemen ke-IV (selanjutnya disebut UUD 1945), disebutkan bahwa: "Negara Indonesia adalah Negara hukum". Konsep negara hukum menurut Aristoteles yang dikutip oleh Moh. Kusnardi dan Harmaily Ibrahim, adalah:

Negara yang berdiri di atas hukum yang menjamin keadilan kepada warga negaranya. Keadilan merupakan syarat bagi tercapainya kebahagian hidup untuk warga negaranya, dan sebagai dasar dari pada keadilan itu perlu dia jarkan rasa susila kepada setiap manusia agar ia menjadi warga negara yang baik. Bagi Aristoteles yang memerintah dalam negara bukanlah manusia sebenarnya, melainkan fikiran yang adil, sedangkan penguasa sebenarnya hanya pemegang hukum dan keseimbangan saja (Kusnardi dan Ibrahim, 1998)

Fitzgerald menjelaskan teori pelindungan hukum bertujuan untuk mengintegrasikan dan mengkoordinasikan berbagai kepentingan dalam masyarakat (Rahardjo. 2010), oleh karena itu, dalam pergaulan hidup di masyarakat yang didalamnya terdapat berbagai kepentingan perlu adanya perlindungan terhadap kepentingan-kepentingan tersebut, baik itu kepentingan yang bersifat individual atau kelompok.

Teori sistem hukum (legal system theory), Sistem hukum menurut Lawrence Milton Friedman di dalamnya terdiri dari beberapa subsistem, yang meliputi substansi hukum 
(legal structure), struktur hukum (legal subtance), dan budaya hukum (legal culture). Ketiga unsur ini menurut Lawrence Milton Friedman di dalam hukum Amerika Serikat tersusun dari yang pertama adalah struktur hukum (legal structure) kemudian diikuti dengan substansi hukum (legal subtance) dan budaya hukum (legal culture) (Friedman, 2001).

Berhasil atau tidaknya penegakan hukum sangat bergantung dari bekerjanya masing-masing subsitem dalam sistem hukum itu sendiri, yaitu substansi hukum, struktur hukum dan budaya hokum (Mahbub, et. al, 2012). Ketiga subsistem ini menggambarkan bagaimana sistem hukum ditata secara substantif, apa yang dijalankan oleh sistem hukum itu, bagaimana sistem hukum itu menjalankannya, yang pada gilirannya akan dapat dilihat keberhasilan dari sistem hukum itu sendiri dengan meningkatnya kesadaran terhadap hukum.

\section{HASIL DAN PEMBAHASAN}

\section{Restorative Justice Dalam Undang-Undang Nomor 11 Tahun 2012 Tentang Sistem} Peradilan Pidana Anak

Penyelesaian perkara anak yang berhadapan dengan hukum dengan menggunakan pendekatan keadilan restorative dilakukan dengan cara pelaksanaan diversi. Pelaksanaan diversi menurut Undang-Undang SPPA, memiliki beberapa tujuan, yaitu : 1) Mencapai perdamaian antara korban dan anak; 2) Menyelesaikan perkara anak di luar proses peradilan; 3) Menghindarkan anak dari perampasan kemerdekaan; 4) Mendorong masyarakat untuk berpartisipasi; dan 5) Menanamkan rasa tanggung jawab kepada anak.

Memperhatikan tujuan pelaksanaan diversi di atas, dapat dipahami bahwa diversi merupakan pengalihan proses penyelesaian permasalahan hukum yang sedang dihadapi oleh anak dari proses peradilan formal ke proses peradilan informal. Dasar hukum pelaksanaan diversi pada penyelesaian perkara anak yang berkonflik dengan hukum oleh penyidik mengacu pada ketentuan Pasal 7 ayat (1) dan (2) Undang-Undang SPPA, yang menyatakan bahwa pada tingkat penyidikan, penuntutan dan pemeriksaan perkara anak di pengadilan, wajib diupayakan diversi. Pelaksanaan diversi dilakukan terhadap tindak pidana yang diancam dengan pidana penjara di bawah tujuh tahun dan bukan merupakan pengulangan tindak pidana. 
Diversi merupakan suatu konsep untuk mengalihkan suatu kasus dari proses formal ke proses informal. Proses pengadilan ditujukan untuk memberikan perlindungan terhadap anak yang berkonflik dengan hokum (Marlina, 2009 ). Diversi merupakan suatu pembaharuan dalam hukum pidana dalam rangka memberikan perlindungan terhadap anak sesuai dengan amanat Undang-Undang Perlindungan Anak.

Undang-Undang Perlindungan Anak menentukan beberapa prinsip perlindungan terhadap anak, yang meliputi: a) Non diskriminasi; b) Kepentingan yang terbaik bagi anak; c) Hak untuk hidup, kelangsungan hidup dan perkembangan; d) Penghargaan terhadap pendapat anak.

Mewujudkan prinsip-prinsip perlindungan anak, maka penyelesaian perkara anak yang berhadapan dengan hukum harus senantiasa memperhatikan kepentingan terbaik bagi anak. Menurut Wagiati Soedtejo, yang dimaksud dengan kepentingan terbaik bagi anak (the best interest of the child) adalah dalam semua tindakan yang menyangkut anak yang dilakukan pemerintah, masyarakat, badan legislatif, dan badan yudikatif, harus demi kepentingan terbaik bagi anak harus menjadi pertimbangan (Soedtejo, 2008).

Prinsip kepentingan terbaik bagi anak, meskipun telah diatur dalam UndangUndang Nomor 3 Tahun 1997 Tentang Pengadian Anak, namun prinsip tersebut belum sepenuhnya mengakomodir dan mendorong terlaksananya perlindungan bagi anak yang berhadapan dengan hukum secara konperehensif. Akibatnya, penyelesaian perkara anak yang berhadapan dengan hukum masih banyak mengabaikan hak-hak anak dan juga tidak didasari pada pertimbangan kepentingan terbaik bagi anak.

Sebelum diberlakukannya Undang-Undang Nomor 11 Tahun 2012 Tentang Sistem Peradilan Pidana Anak, perlindungan terhadap anak yang berhadapan dengan hukum begitu sangat memprihatinkan. Beberapa kasus penanganan perkara anak yang berhadapan dengan hukum tidak sesuai dengan semangat dan roh dari Undang-Undang Perlindungan Anak. Sehingga dalam proses penanganan anak yang berhadapan dengan hukum telah berdampak pada psikis anak yang menimbulkan traumatis dan frustasi bagi anak.

Pembaharuan hukum peradilan pidana anak dilakukan dengan menerapkan konsep baru dalam penanganan perkara anak yang berkonflik dengan hukum, yaitu dengan mengalihkan proses peradilan pidana anak dari peradilan formal ke peradilan informal (diversi). Diversi dalam penanganan anak yang berkonflik dengan hukum dilaksanakan 
melalui pendekatan keadilan restorative, sesuai Pasal 5 ayat (1) Undang-Undang SPPA, yang menyebutkan: "Sistem Peradilan Pidana Anak wajib mengutamakan pendekatan Keadilan restoratif.

Keadilan restoratif memperoleh inspirasi dari "community justice" (peradilan atau keadilan masyarakat) yang masih dipergunakan pada beberapa budaya masyarakat non Barat, khususnya masyarakat adat Indonesia. Perkembangannya, konsep restorative justice dipengaruhi oleh pemikiran mengenai persamaan dalam hubungan masyarakat. Meskipun inspirasi restorative justice tidak datang dari masyarakat Indonesia, namun pola-pola restorative justice tertanam dalam beberapa tradisi masyarakat adat di Indonesia (Soedtejo, ...). Saat ini Indonesia telah memiliki Undang-Undang Nomor 11 Tahun 2012 tentang Sistem Peradilan Pidana Anak sebagai bentuk ratifikasi dari Konvensi Hak-hak Anak (Convention on the Rights of the Child) 20 November 1989.

Berdasarkan ketentuan Pasal 7 ayat (1), pelaksanaan diversi wajib diupayakan pada tingkat penyidikan, penuntutan, dan pemeriksaan perkara Anak di pengadilan. Hal ini berarti diversi dapat diupayakan dan dilaksanakan pada tiap tingkatan proses peradilan pidana, yang meliputi: diversi pada tingkat penyidikan, penuntutan dan pemeriksaan di pengadilan dengan mempertimbangkan: 1) Kategori tindak pidana; 2) Usia Anak; 3) Kesediaan (persetujuan) korban dan dukungan keluarga korban untuk pelaksanaan diversi; 4) Pengakuan dan penyesalan pelaku; 5) Dukungan masyarakat.

Berdasarkan uraian di atas, dapat disimpulkan dalam penyelesaian perkara anak yang berhadapan dengan hukum, maka penyidik, penuntut umum ataupun hakim berkewajiban untuk mengupayakan diversi dengan mengedepankan penyelesaian berdasarkan keadilan restoratif. Memenuhi kewajibannya tersebut, dalam penyelesaian perkara anak yang berhadapan dengan hukum aparat penegak hukum dalam sistem peradilan pidana anak senantiasa harus mengedepankan kepentingan terbaik bagi anak, yaitu dengan pelaksanaan diversi. Dalam pelaksanaan diversi oleh penyidik, maka terdapat beberapa hal yang menjadi pertimbangan, yaitu kategori tindak pidana, umur anak, hasil penelitian kemasyarakatan dari Balai Pemasyarakatan (Bapas), kerugian yang ditimbulkan, tingkat perhatian masyarakat, dan dukungan lingkungan keluarga dan masyarakat. 


\section{Restorative Justice Sebagai Upaya Perlindungan Terhadap Anak Yang Berhadapan Dengan Hukum}

Konsepsi perlindungan anak meliputi ruang lingkup yang sangat luas, dalam arti perlindungan anak tidak hanya mengenai perlindungan atas jasmani dan rohani anak, tetapi juga mengenai perlindungan atas semua hak dan kepentingannya yang dapat menjamin pertumbuhan dan perkembangan yang wajar, secara rohani, jasmani maupun sosialnya (Gultom, 2008).

Upaya perlindungan hukum bagi anak, khususnya perlindungan hukum bagi anak yang berhadapan dengan hukum, dalam Undang-undang Nomor 11 Tahun 2012 tentang Sistem Peradilan Pidana Anak telah diatur khusus mengenai diversi dan keadilan restoratif dalam penyelesaian perkara anak yang tentunya dengan tujuan agar hak-hak anak dalam hal ini yang bermasalah dengan hukum lebih terlindungi dan terjamin. Undang-Undang ini menentukan bahwa pada tingkat penyidikan, penuntutan dan pemeriksaan perkara Anak di pengadilan negeri wajib diupayakan Diversi, pada tiap tingkatan proses peradilan pidana anak.

Diversi dalam penanganan anak yang berkonflik dengan hukum dilaksanakan melalui pendekatan keadilan restoratif sesuai dengan Pasal 5 ayat (1) Undang-Undang SPPA, yang menyebutkan: "Sistem Peradilan Pidana Anak wajib mengutamakan pendekatan Keadilan restoratif".

Perlindungan hukum terhadap anak yang berhadapan dengan hukum dengan penerapan keadilan restoratif melalui pelaksanaan Diversi dalam penanganan perkara pidana, Jonlar Purba menjelaskan sebagai berikut:

Penanganan perkara pidana dengan pendekatan keadilan restorative justice menawarkan pandangan pdan pendekatan berbeda dalam memahami dan menangani suatu tindak pidana. Dalam pandangan keadilan restoratif makna tindak pidana pada dasarnya sama seperti pandangan hukum pidana pada umumnya yaitu serangan terhadap individu dan masyarakat serta hubungan kemasyarakatan. Akan tetapi, dalam pendekatan restorative, korban utama atas terjadinya suatu tindak pidana bukanlah negara, sebagaimana dalam sistem peradilan pidana yang sekarang ada. Oleh karenanya kejahatan menciptakan kewajiban untuk membenahi rusaknya hubungan akibat terjadinya suatu tindak pidana. Sementara keadilan dimaknai sebagai proses pencarian pemecahan masalah yang terjadi atas suatu perkara pidana di mana keterlibatan korban, 
masyarakat dan pelaku menjadi penting dalam usaha perbaikan, rekonsilisasi dan penjaminan keberlangsungan usaha perbaikan tersebut (Purba, 2017).

Diversi merupakan suatu konsep untuk mengalihkan suatu kasus dari proses formal ke proses informal. Proses pengadilan ditujukan untuk memberikan perlindungan terhadap anak yang berkonflik dengan hokum (Marlina, 2009). Konsep Diversi merupakan suatu pembaharuan dalam hukum pidana dalam rangka memberikan perlindungan terhadap anak.

Mewujudkan prinsip-prinsip perlindungan anak dalam penyelesaian perkara anak yang berhadapan dengan hukum harus senantiasa memperhatikan kepentingan terbaik bagi anak. Kepentingan terbaik bagi anak (the best interest of the child) adalah dalam semua tindakan yang menyangkut anak yang dilakukan oleh pemerintah, masyarakat, badan legislatif, dan badan yudikatif, maka kepentingan terbaik bagi anak harus menjadi pertimbangan.

Penerapan diversi dalam penyelesaian perkara anak yang berhadapan dengan hukum memiliki konsekuensi hukum dihentikannya penyidikan, apabila antara korban dan pelaku terdapat kesepakatan diversi atau tercapai kesepakatan perdamaian antara korban dengan pelaku atau antara keluarga korban dan keluarga pelaku. Dengan demikian, tujuan perlindungan hukum terhadap anak yang berhadapan dengan hukum dapat terwujud, yaitu menjauhkan anak dari proses peradilan formal.

Berdasarkan hasil penelitian dibeberapa instansi pemerintah dan lembaga hukum terkait dengan pelaksanaan restorative justice dalam sistem peradilan pidana anak, secara umum menyatakan bahwa restorative justice merupakan upaya perlindungan terhadap anak yang berhadapan dengan hukum. Hal ini dapat diketahui dari berbagai keterangan yang diperoleh dari hasil penelitian sebagia berikut:

Wayu Ratna selaku Kepala Dinas Pemberdayaan Perempuan dan Perlindungan Anak Kota Dumai, menyatakan (Wawancara dengan Wahyu Ratna, selaku Kepala Dinas Pemberdayaan Perempuan dan Perlindungan Anak Kota Dumai pada tanggal 18 Maret 2019) :

Restorative justice dapat memberikan perlindungan terhadap anak yang berhadapan dengan hukum karena mengutamakan prinsip kepentingan terbaik bagi anak dengan tetap tidak mengabaikan hak-hak anak karena dengan pelaksanaan restorative justice dilakukan dengan cara melakukan musyawarah, pendekatan 
kekeluargaan antara pelaku, korban dan masyarakat sehingga sedapat mungkin menghindarkan anak dari lembaga peradilan dan hak azasi anak dapat lebih terjamin serta menghindarkan anak dari stigma sebagai "anak nakal” yang pada akhirnya dapat memulihkan hubungan antara korban dan pelaku guna keadilan dan keseimbangan bagi korban dan pelaku.

Hasan Basri, selaku pembina Tk. I di Dinas Sosial Pemerintahan Kota Dumai (pada tanggal 19 Maret 2019), menyatakan: Tentu saja restorative justice sangat bermanfaat dalam perlindungan terhadap anak yang berkonfilik dengan hukum, dimana pihak korban, pelaku, keluarga, dan masyarakat mendapatkan edukasi untuk tidak melakukan tindakan dan reaksi negatif terhadap anak yang berkonflik hukum namun diharapkan memberikan tindakan merangkul sehingga anak yang berhadapan dengan hukum tidak merasa didiskriminasi dan tidak akan mengulanginya lagi.

Ria Narfiady, selaku Ketua Pimpinan Cabang Ikatan Advokat Indonesia (IKADIN) Kota Dumai, menyatakan bahwa (tanggal 15 Maret 2019): Restorative justice dapat memberikan perlindungan terhadap anak yang berkonflik dengan hukum. Restorative justice merupakan upaya untuk memperlakukan anak yang berkonflik dengan hukum sesuai dengan martabatnya. Proses pada peradilan pidana yang dilakukan oleh aparat penegak hukum apabila pelaku anak terbukti bersalah, idealnya dan sudah seharusnya dijatuhi tindakan dikembalikan kepada orang tua. Upaya melaksanakan perintah undang-undang agar penjatuhan pidana penjara terhadap anak merupakan upaya terakhir.

Roslina, Jaksa Penuntut Umum di Kejaksaaan Negeri Dumai, menerangkan sebagai berikut (tanggal 14 Maret 2019): Konsep restorative justice dapat memberikan perlindungan terhadap anak yang berkonflik dengan hukum dikarenakan anak yang berkonflik dengan hukum tersebut tidak dilakukan pernahanan sebagaimana orang dewasa sehingga anak yang berkonflik dengan hukum tersebut masih mempunyai hakhaknya seperti hak untuk sekolah dan juga tidak harus mengalami proses persidangan.

Abdi, B. K Siregar, Penyidik Pembantu pada Unit Pelayanan Perempuan dan Anak Polsek Dumai Barat, menjelaskan sebagai berikut (tanggal 15 Maret 2019): Restorative justive dapat memberi perlindungan terhadap Anak yang berkomplik dengan hukum karena pemidanaan anak tidak menjamin anak akan menjadi baik setelah menjalani proses pemidanaan tersebut sehingga perlu dilakukan proses yang baik untuk 
kepentingan Anak namun restorative justive terhadap anak yang berkomplik hukum juga tidak boleh meniadakan keadilan terhadap korban atas perbuatan anak tersebut.

Berdasarkan pendapat dari berbagai instansi pemerintah dan lembaga penegak hukum di atas, dapat disimpulkan bahwa penerapan restorative justice dalam penyelesaian perkara pidana anak akan memberikan perlindungan hukum terhadap anak. Dengan peralihan penyelesaian perkara dari peradilan pidana formal ke informal, maka tentunya akan membebaskan anak dari stigma buruk di masyarakat karena penjatuhan pidana oleh pengadilan.

Penerapan restorative justice dalam penyelesaian perkara tindak pidana anak tidak saja memberikan perlindungan hukum bagi anak yang berhadapan dengan hukum, tetapi juga memberikan perlindungan terhadap hak-hak korban. Oleh karena itu, penerapan restorative justice juga mencerminkan keadilan, yaitu keadilan bagi korban dan juga bagi pelaku. Hal ini didasarkan teori keadilan yang menganggap kejahatan dan pelanggaran, pada prinsipnya adalah pelanggaran terhadap individu atau masyarakat dan bukan kepada negara.

\section{Faktor-Faktor Penghambat Dalam Pelaksanaan Restorative Justice Dan Solusinya Di Wilayah Hukum Pengadilan Negeri Kelas Dumai IA}

Menurut Lawrence Milton Friedman, sistem hukum didalamnya terdiri dari beberapa subsistem, yang meliputi substansi hukum (legal structure), struktur hukum (legal subtance), dan budaya hukum (legal culture). Ketiga unsur ini menurut Lawrence Milton Friedman di dalam hukum Amerika Serikat tersusun dari yang pertama adalah struktur hukum (legal structure) kemudian diikuti dengan substansi hukum (legal subtance) dan budaya hukum (legal culture) (Friedman, 2008)

Berhasil atau tidaknya penegakan hukum sangat bergantung dari bekerjanya masing-masing subsitem, yaitu substansi hukum, struktur hukum dan budaya hokum (Mahbub et.al, 2012). Ketiga subsistem ini menggambarkan bagaimana sistem hukum ditata secara substantif, apa yang dijalankan oleh sistem hukum itu, bagaimana sistem hukum itu menjalankannya, yang pada gilirannya akan dapat dilihat keberhasilan dari sistem hukum itu sendiri dengan meningkatnya kesadaran terhadap hukum.

Hambatan penerapan restorative justice dalam penyelesaian perkara anak yang berhadap dengan hukum di wilayah hukum Pengadilan Negeri Dumai Kelas IA, apabila 
dihubungkan dengan teori sistem hukum, maka terdapat dua faktor yang mempengaruhi penerapan restorative justice dalam penyelesaian perkara anak, yang dapat diuraikan sebagai berikut:

Dari Faktor struktur hukum, Penyelesaian penyelesaian perkara anak yang berhadapan dengan hukum sangat dipengaruhi oleh aktor penegak hukum (struktur hukum). Artinya, sebaik apapun aturan hukum, dalam penerapannya sangat tergantung pada kemampuan aparatur penegak hukumnya, jika aparat penegak hukum tidak mempunyai kemampuan memadai dalam melaksanakan penegakan hukum, maka hukum yang baik itu tidak akan dapat memberikan manfaat bagi masyarakat (Sinaga \& Elvi, 2010; Nainggolan, Elvi \& Saparuddin, 2010).

Penerapan diversi melalui pendekatan keadilan restorative dalam penyelesaian perkara anak yang berhadapan dengan hukum, baik penyidik, penuntut umum, maupun hakim sebagai penegak hukum sangat memiliki peran dalam menentukan keberhasilan proses diversi. Dengan kata lain, penegak hukum sangat menentukan keberhasilan penerapan restorative justice dalam sistem peradilan pidana anak.

Dimaksud dengan stuktur hukum dalam penerapan restorative justice, yaitu terkait ketersediaan sumber daya dalam pelaksanaan substansi Undang-Undang SPPA, yang meliputi: sumber daya aparat penegak hukum, sarana dan prasana dan anggaran. Berkenaan dengan sumber daya aparat penegak hukum dalam sistem peradilan pidana anak, dapat dikatakan bahwa hampir diseluruh lembaga penegak hukum mengakui masih kekurangan Sumber Daya Manusia yang mendukung pelaksanaan Undang-Undang SPPA.

Sesuai pendapat yang disampaikan oleh Abdi. K Siregar (15 Maret 2019), selaku penyidik pembantu pada unit pelayanan Perempuan dan Perlindungan Anak, Polsek Dumai Barat, yang menyatakan bahwa "personil penyidik khusus anak di Polres Dumai masih sangat kurang. Selain itu pelatihan dan pendidikan khusus bagi penyidik anak juga masih sangat minim." Hal senada juga disampaikan oleh Hasan Basri, selaku Pembina Tk. Dinas Sosial Kota Dumai (pada tanggal 19 Maret 2019), yang menyatakan bahwa hambatan dalam pelaksanaan restorative justice disebabkan beberapa faktor, diantaranya adalah: 1) Masih kurangnya pengetahuan penyidik mengenai UndangUndang SPPA No. 11 Tahun 2012; 2) Ketidakpahaman masyarakat pada umumnya terkait Undang-Undang SPPA. No. 11 Tahun 2012; 3) Penegak hukum yang belum 
melaksanakan secara optimal Undang-Undang SPPA. No. 11 Tahun 2012 dan masih bersikap kaku; 4) Kordinasi antar aparat penegak hukum belum sepenuhnya dapat tercapai.

Penyediaan Sumber Daya Manusia dalam mendukung pelaksanaan Undang-Undang SPPA begitu urgen, namun demikian aparat penegak hukum, khusus penyidik, penuntut anak, dan hakim anak masih sangat minim. Selain minimnya jumlah personil, dilihat dari kualitas aparat penegak hukum yang menangani perkara anak, baik itu penyidik anak, penuntut anak, dan hakim anak masih sangat kurang. Hal ini dikarenakan minimnya pelatihan dan pendidikan terhadap aparat penegak hukum. Hal ini sesuai dengan pernyataan yang disampaikan oleh Mulkan Siregar, selaku Bapas pada pos Bapas Dumai (pada tanggal 15 Maret 2019), sebagai berikut:

Dilihat dari kualitas sumber daya manusia aparat penegak hukum yang menangani perkara anak, dapat dikatakan bahwa pemahaman aparat penegak hukum yang menangani perkara anak di wilayah hukum Pengadilan Negeri Dumai Kelas I A masih sangat minim. Hal ini dikarenakan belum ada Penyidik Anak dan Jaksa Anak yang sudah mengikuti Diklat sebagai Penyidik Anak dan sebagai Jaksa Anak.

Penyelenggaraan pendidikan dan pelatihan bagi aparatur penegak hukum selalu dihadapkan pada keterbatasan anggaran yang dimiliki oleh masing-masing lembaga penegak hukum. Demikian pula pembangunan sarana dan prasana yang mendukung terlaksananya proses restorative justice, juga masih terkendala dengan anggaran yang tersedia (Zai, Taufik \& Dedy, 2011; Faidir \& Marlina, 2012).

Sebagai akibat terbatasnya penegak hukum yang mendukung terlaksananya sistem peradilan pidana, baik dilihat dari segi kuantitas maupun kualitasnya, tentu akan berdampak pada penerapan restorative justice dalam sistem peradilan pidana anak. Oleh karena, penerapan restorative justice dalam sistem peradilan pidana anak membutuhkan pemahaman dari aparat penegak hukum.

Pada Faktor budaya hukum, Penegakan hukum bukanlah suatu hal yang berdiri sendiri, melainkan ia saling berkait dengan masalah-masalah sosial masyarakat lainnya. Artinya hukum bukan hanya sebagai sistem nilai, tetapi juga hukum sebagai sub sistem dari sistem sosial yang lebih besar, yaitu masyarakat di mana hukum diberlakukan.

Budaya hukum merupakan penerimaan atau penolakan terhadap suatu peristiwa hukum yang menunjukan setiap perilaku manusia terhadap masalah hukum dan 
peristiwa hukum yang terbawa ke dalam masyarakat. dengan demikian, budaya hukum adalah keseluruhan faktor yang menentukan bagaimana sistem hukum memperoleh tempatnya yang logis dalam kerangka budaya milik masyarakat umum (Soekanto, ).

Budaya hukum adalah tanggapan umum yang sama dari masyarakat tertentu terhadap gejala-gejala hukum. Tanggapan itu merupakan kesatuan pandangan terhadap nilai-nilai dan perilaku hukum. Jadi, suatu budaya hukum menunjukkan tentang pola perilaku individu sebagai anggota masyarakat yang menggambarkan tanggapan (orientasi) yang sama terhadap hukum yang dihayati masyarakat bersangkutan.

Harus pula disadari bahwa persepsi warga masyarakat menjadi sasaran diberlakukannya suatu perundang-undangan, tidak selalu sama dengan persepsi pembuat undang-undang. Untuk itu, pembuat undang-undang sedapat mungkin harus memperhatikan nilai-nilai yang hidup serta kepentingan warga masyarakat ketika merumuskan undang-undang.

Beranjak dari pernyataan tersebut, peraturan perundang-undangan, khususnya yang terkait dengan penyelesaian perkara pidana yang diatur dalam KUHAP, hendaknya diselaraskan dengan nilai-nilai hukum yang telah menjadi budaya hukum masyarakat, yaitu adanya kelaziman dalam masyarakat untuk menyelesaikan persoalan-persoalan yang dihadapi dengan cara bermusyawarah untuk mencapai mufakat.

Cara-cara penyelesaian sengketa melalui musyawarah merupakan budaya hukum masyarakat yang telah berkembang sejak lama, menghargai permohonan maaf dari pelaku atas kesalahan yang telah dilakukannya adalah bentuk pencerminan budaya hukum masyarakat Indonesia. Jadi, meskipun pemulihan terhadap korban merupakan syarat utama dalam pelaksanaan penyelesaian perkara anak yang berhadapan dengan hukum, namun bukan berarti pemulihan korban dengan cara memberi ganti kerugian menjadi hal mendasar dalam pelaksanaan diversi. Hal paling mendasar dalam proses penyelesaian perkara anak yang berhadapan dengan hukum melalui pelaksanaan Diversi adalah adanya keinginan pelaku untuk mengakui kesalahannya dan memohon maaf kepada korban. Sebaliknya, korban yang mengalami kerugian dan penderitaan akibat perbuatan pelaku harus berlapang dada dan ikhlas untuk memaafkan pelaku.

Permohonan maaf dari pelaku kepada korban merupakan wujud iktikad baik dari sikap pelaku terhadap korban. Pada tahap selanjutnya, barulah kemudian dipertimbangkan besarnya jumlah ganti kerugian yang harus ditanggung oleh pelaku 
sebagai bentuk pemulihan terhadap korban dan tanggung jawab pelaku terhadap penderitaan yang dialami korban akibat dari perbuatan yang dilakukan oleh pelaku.

Berkaitan dengan pemulihan hak-hak korban yang terwujud dalam bentuk ganti kerugian, lazim dilakukan negosisasi antara korban dan pelaku untuk mencapai kesepakatan mengenai kesanggupan pelaku untuk menanggung beban ganti kerugian yang diderita oleh korban. Dengan demikian, inti dari pelaksanaan Diversi adalah adanya sikap saling memaafkan kesalahan orang lain yang merupakan cerminan budaya masyarakat Indonesia. yakni senantiasa menjalin hubungan baik dengan orang lain.

Berdasarkan uraian di atas, dapat dikatakan bahwa pelaksanaan diversi melalui pendekatan keadilan restorative dalam penyelesaian perkara anak yang berhadapan dengan hukum menemukan beberapa hambatan. Hambatan yang dialami paling signifkan dan sangat menentukan dalam penyelesaian perkara anak yang berhadapan dengan hukum melalui diversi adalah sulitnya mempertemukan keseimbangan pelbagai kepentingan dari para pihak, yaitu pelaku, korban, dan masyarakat sehingga proses diversi mengalami kegagalan.

\section{SIMPULAN}

Konsep restorative justice dalam Undang-undang Nomor 11 Tahun 2012 Tentang Sistem Peradilan Pidana Anak, dilaksanakan melalui penerapan Diversi pada setiap tingkat proses peradilan pidana anak, yang meliputi: pada tahap penyidikan, penuntutan dan pemeriksaan di pengadilan. Diversi merupakan pengalihan penyelesaian perkara anak yang berhadapan dengan hukum dari proses formal (proses peradilan) ke proses in formal, dengan cara musyawarah dan mufakat yang mengedepankan keadilan restorative. Pelaksanaan restorative justice melalui penerapan diversi dapat memberi Perlindungan terhadap Anak, karena penetapan Diversi pada penyelesaian perkara anak yang berhadapan dengan hukum akan menghindarkan anak dari proses peradilan formal yang dimungkinkan terabaikannya hak-hak anak dan menimbulkan trauma bagi anak. Selain itu, penetapan diversi juga akan menghindari anak dari stigma negative dari masyarakat dan selalu mempertimbangkan kepentingan terbaik bagi anak. Faktor menjadi hambatan dalam pelaksanaan restorative justice di wilayah hukum Pengadilan Negeri Dumai Kelas I A adalah masih kurangnya SDM aparatur penegak hukum baik dilihat dari kuantitas maupun kualitasnya. Sarana dan prasana pendukung masih sangat 
minim, karena keterbatasan anggaran. Masih kurangnya sosialisasi kepada masyarakat, sehingga menyebabkan persepsi masyarakat masih belum seragam terkait penerapan restorative justice dalam penyelesaian tindak pidana yang dilakukan oleh anak. Solusi dalam mengatasi hambatan penerapan restorative justice, adalah peningkatan kuantitas dan kualitas aparat penegak hukum. Penambahan sarana dan prasana yang mendukung terlaksananya perlindungan hukum terhadap anak.

\section{DAFTAR PUSTAKA}

Departemen Pendidikan Nasional (2010), Kamus Besar Bahasa Indonesia, Penerbit Balai Pustaka, Jakarta, 2010.

Faidir, dan Marlina, (2012), Peran Polri dalam Proses Penyidikan Tindak Pidana terhadap Anak Yang Berkonflik dengan Hukum, Mercatoria, 5 (1): 12-22

Friedman, M.L, (2001). Hukum Amerika Sebuah Pengantar, terjemahan Wishnu Basuki, Tatanusa, Jakarta.

Ginting, H. \& Muazzul (2018). Peranan Kepolisian dalam Penerapan Restorative Justice terhadap Pelaku Tindak Pidana Pengeroyokan yang Dilakukan oleh Anak dan Orang Dewasa, Jurnal Ilmiah Penegakan Hukum, 5 (2): 32-40.

Gultom, M, (2008). Perlindungan Hukum Terhadap Anak dalam Sostem Peradilan Pidana Anak di Indonesia, Refika Aditama, Bandung.

Ibrahim, H. \& Ku snardi, M. (1998). Hukum Tata Negara Indonesia, Sinar Bakti, Sinar Grafika, Jakarta.

Keadilan Restorasi, sumber http://www.negarahukum.com, diakes pada tanggal 18 Maret 2019. Pukul 17.30 Wib.

Mahbub, M, et. al, (2012). Dialektika Pembaharuan Sistem Hukum Indonesia, Sekretaris Jenderal Komisi Yudisial Indonesia, Jakarta, 2012.

Marlina, (2009). Peradilan Pidana Anak di Indonesia: Pengembangan Konsep Diversi dan Restorative Justice, Refika Aditama, Bandung.

Nainggolan, M., Elvi Z., dan Saparuddin, (2010), Peranan Hakim dalam Memberikan Perlindungan Hukum terhadap Anak Korban Penyalahgunaan Narkotika (Studi Pengadilan Negeri Lubuk Pakam), Mercatoria, 3 (2): 116-132

Peraturan Mahkamah Agung tentang Pedoman Pelaksanaan Diversi Dalam Sistem Peradilan Pidana Anak, Peraturan Mahkamah Agung Nomor 4 Tahun 2014.

Purba, (2017). Penegakan Hukum Terhadap Tindak Pidana bermotif Ringan Dengan Restoratif Justice, Permata Aksara, Jakarta.

Purba, D \& Zahara, E (2017). Hak Terhadap Anak Setelah Perceraian Yang Diakibatkan Oleh Pertengkaran Suami Istri. Jurnal Ilmiah Penegakan Hukum 4 (1) 2017: 16-22

Rahardjo, S, (2010). llmu Hukum, Citra Aditya Bakti, Bandung, 2010.

Rahardjo, S, (2016). Hukum Progresif Sebuah Sintesa Hukum Indonesia, Penerbit Publisihing, Yokyakarta, 2016.

Sidabutar, R. \& Suhatrizal. (2018). Perlindungan Hukum terhadap Anak yang Melakukan Tindak Pidana Pencabulan pada Putusan No.2/pid.sus/2014PN.Mdn. Jurnal Ilmiah Penegakan Hukum, 5 (1): 2231.

Sinaga, S.M., dan Elvi Z.L., (2010), Perlindungan Hukum terhadap Anak Yang Melakukan Kejahatan dalam Persidangan Anak, Mercatoria, 3 (1): 52 - 57

Soekanto, S, (2010). Faktor-Faktor Yang Mempengaruhi Penegakan Hukum, Rajawali Pers, Jakarta.

Soekanto, S. (2012). Pengantar Penelitian Hukum, Universitas Indonesia Press, Jakarta.

Soekanto, S. dan Sri, P, (2013). Penelitian Hukum Normatif: Suatu Tinjauan Singkat, Raja Grafindo Persada, Jakarta.

Supeno, H, (2015). Kriminalisasi Anak, Gramedia Pustaka Utama, Jakarta.

Undang-Undang Dasar 1945 setelah amandemen.

Undang-Undang tentang Hak Asasi Manusia, Undang-Undang Nomor 39 Tahun 1999, LN No 165 Tahun 1999, TLN 3886.

Undang-Undang tentang Perlindungan Anak, Undang-Undang Nomor 23 Tahun 2002, LN Nomor 109 Tahun 2002, TLN 4235. 
Undang-Undang tentang Sistem Peradilan Pidana Anak, Undang-Undang Nomor 11 Tahun 2012. Waluyadi, (2009). Hukum Perlindungan Anak, Mandar Maju, Bandung.

Zai, A., Taufik S., dan Dedy I., (2011), Perlindungan Hukum Terhadap Anak yang Berhadapan dengan Hukum dalam Sistem Peradilan Anak, (Studi pada Wilayah Hukum Polres Nias), Mercatoria, 4 (2): 86-103 